\title{
Challenging the New "One-Dimensional Man": The Protestant Orders of Life as a Critical Nuance to Workplace Spirituality
}

\author{
Steven C. van den Heuvel
}

\begin{abstract}
While recognizing the increased attention to spirituality in the workplace as being a good development overall, this chapter focuses on some problematic aspects of this new emphasis. In particular, three problems are identified: (1) the danger of instrumentalization and narcissistic misdirection; (2) the adoption of pragmatism in solving conflicts between conflicting spiritualities in the workplace, and (3) the dominance of radical social constructivist approaches, which don't take into consideration the metaphysical claims inherent in many (especially religious) forms of spirituality. Together, these problems amount to a new "one-dimensionality," referring to the famous description of modern society by Herbert Marcuse. In order to address these problems, I make recourse to the Protestant concept of the different orders of life, particularly as developed by the German theologian Dietrich Bonhoeffer. In this chapter, I focus on three characteristics of his concept and argue that they can help in addressing the problems with the new emphasis on workplace spirituality that I have identified.
\end{abstract}

\section{Introduction: The New Quest for Spirituality in the Workplace}

The background to this volume is the enormous increase in the attention being paid to the theme of spirituality in the workplace. This upsurge can be understood in a number of different ways. On the one hand, it can be seen as an expression of the dramatic changes taking place in the nature of work, especially in the West. From the predominantly repetitive and mechanical work in factories during the era of

\footnotetext{
The original version of this chapter was revised. A correction to this chapter is available at https://doi.org/10.1007/978-3-319-98884-9_13.

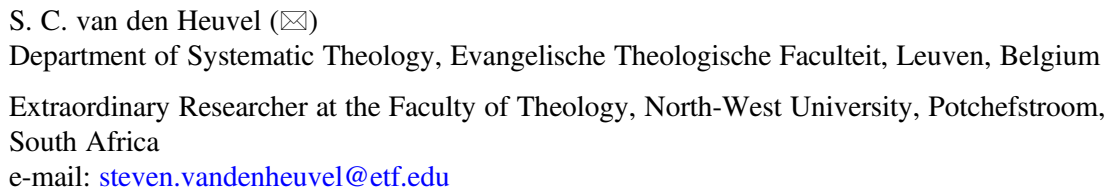


industrialization, the West has moved towards a service economy, and is currently moving increasingly towards an information economy. This dynamic has been noted by many researchers. Thomas Friedman, for example, speaks about the current era as being the "age of accelerations" (Friedman 2016). ${ }^{1}$ Spirituality, as a quest for unity and meaning, can be seen as the desire for an answer in this context of fraction and change. This renewed focus on the individual makes the personal and spiritual wellbeing of the employee vitally important to the competitive success of an organization in a way that has not been widely recognized before (see, for example, Holman et al. 2005). Many studies show how a focus on spirituality is positively correlated with greater worker performance. They demonstrate how workers who score well on the indicators of spiritual wellbeing can deal better with workplace stress and job overload and enjoy more job satisfaction. ${ }^{2}$

A second reason for the upsurge in spirituality in the workplace is a genuine interest on the part of both employers as well as employees, an interest that goes beyond the instrumental use of spirituality as a way of boosting employee performance. In fact, many people with an interest in spirituality might say that such an instrumental view betrays the very intention with which they seek to develop their spiritual growth-this intention will most often be characterized as genuine, non-instrumental value-directedness. As such, renewed spirituality in the workplace is the expression of an old and profound realization, namely that one's place of work is not just a way of making money to fund a life lived outside of the organization. This latter view can best be understood, in fact, as a result of the mechanization and dehumanization of work in the industrial era. It is conceivable that work loses its meaning for the factory worker who has to perform monotonous tasks over and over again, day in day out. That worker might try to find meaning elsewhere, or, more likely, drown its loss-quite literally—in the café. As mechanical and dehumanizing labor has almost disappeared in the West, it has become possible for the majority of people to once more seek a connection between their work and their spirituality. In that sense the new quest for spirituality is really not that new, to be understood primarily as a reaction, but is rather the re-emergence of an age-old endeavor.

While recognizing the genuine interest in workplace spirituality, in this chapter I nevertheless take a critical distance, discerning several problems with this interest. I will focus on three in particular: (1) the danger of instrumentalization and narcissistic misdirection, (2) the use of pragmatism as a framework for solving conflicts between spiritualities, and (3) the social constructivism inherent in many pleas for workplace spirituality. I then attempt to address these problems by means of the uniquely Lutheran concept of the different orders of life, specifically as set out by the German theologian, Dietrich Bonhoeffer. In particular, I focus on his proposal of the different "mandates," which represents his interpretation of the Lutheran concept of the orders

\footnotetext{
${ }^{1}$ See also the chapter "Discerning Spirituality for Missional Leaders" by Nelus Niemandt in this volume.

${ }^{2}$ Some examples are Atlaf and Awan (2011); Marques and Dhiman (2014); Gupta et al. (2014); and Moran (2010). For an overview, see Lambert III (2009).
} 
of life. I will argue that consideration of these mandates can help address the problems identified with contemporary appeals for workplace spirituality. First, the mandates can act as a restraint on attempts to instrumentalize and abuse workplace spirituality. Second, the mandates form an alternative way of appropriating spiritual pluralism. Thirdly and finally, they allow for a constructionist approach to workplace spirituality, while similarly helping to resist radical social constructivism.

\section{Problems with the Appeal for a "New Spirituality"}

The contemporary appeal for spirituality in the workplace is understandable-indeed, for the reasons given above it is almost inevitable that spirituality will end up high on the agenda. Yet while understandable, and mostly commendable, the existence of different motives for this contemporary interest nevertheless also gives rise to difficulties and dangers. In particular, I identify three problems.

\subsection{The Danger of Instrumentalization and Narcissistic Misdirection}

As already suggested, organizations - especially in competitive businesses - may have a less-than-genuine interest in stimulating the spiritual development of their employees. They might be primarily interested in increasing the productivity rates of their employees by paying more attention to workspace spirituality, with the expected benefit of increased resistance to stress and excessive workload, as well as increased creativity and originality. This motive has been explored by Tourish and Pinnington, amongst others, who speak cynically about transformational leadership, corporate cultism, and the spirituality paradigm as being a new "unholy Trinity," whose aim is to create a false sense of consent among workers and to fire them on to work more, and harder (Tourish and Pinnington 2002).

While some degree of commercialization or instrumentalization of spirituality may seem inevitable, it becomes a different story when requirements for spiritual investment are put up front as a precondition for work at the organization; and when, consequently, an employee's spiritual reservoir is tapped by the organization-sometimes until it is empty. There is a certain naïveté about this danger in the writings of some management gurus. Peter Block, for example, expressly asks employees to put themselves in the vulnerable situation of owning the organizational processes in which they are involved, as if they actually did control or own them. He identifies this posture as stewardship (Block 1993). While he clarifies that this attitude isn't one of meekness, but rather of fortitude-he makes approving references to the philosophy of Friedrich Nietzsche in this context, for example-it is nevertheless clear that it could expose the employee to considerable stress if they feel responsible for processes that they ultimately don't control. 
There is a further danger: passionate calls for spiritual investment in an organization can easily become part of the toolbox of the manipulative and the narcissistic leader. The much-studied example of Steve Jobs is a good example of someone who demanded from his staff a deep personal and spiritual commitment to Apple and to the products the company was developing. While he indeed managed to greatly inspire many employees, getting them to give their best, there was also a very dark side to this management style, one that Walter Isaacson refers to as his "reality distortion field" (Isaacson 2011, passim). While hugely inspiring on the one hand, Jobs was also instrumental in the psychological breakdown of a number of employees, due to his demanding and manipulative leadership style.

Instances such as these point to the potentially very negative consequences of a deep entanglement between the spirituality of employees and that of a company. History provides many disturbing examples of these consequences. Vladimir Tarassenko, for example, points out that in the Soviet Union workers were urged to invest deeply and personally in the state endeavors for which they were enlisted. The rhetoric around such appeals sounded sincere and innocent, but in reality it was a means to overcome any internal resistance the "workers" might have had against the communist imperialism that tried to swallow them up whole (Tarassenko 2006, 2008). ${ }^{3}$ Similar attempts at overcoming the distinction between personal and organizational spiritual goals were made in Nazi Germany (see Van den Heuvel 2017b).

\subsection{Pragmatism as the Solution to Conflicting Spiritualities}

People differ widely in their definition of spirituality, as well as in the way they practice it. Although in literature much care is taken to distinguish between religion and spirituality (see, for example, Mitroff and Denton 1999; Phipps and Benefiel 2013), in practice there is a large overlap between religious belief and spirituality in the workplace. This case has been made strongly by Douglas Hicks- he argues that religion is wrongfully overlooked in discussions of spirituality in the workplace (Hicks 2003; this point is also made by Zinnbauer and Pargament 2005). This of course raises the question of how to negotiate religious conflict at the workplace. Focusing particularly on this question, Hicks develops his theory of "respectful pluralism." Central to this theory are the concepts of respect and of human dignity. He gives these guidelines a personalist basis_according to him, "[p]ersons simply have dignity and deserve to be accorded respect because they are human" (Hicks 2003, p. 167). The third guiding principle, undergirding those of respect and dignity, is that of equality - according to him, ". . . all human beings possess equal dignity and thus deserve equal respect" (Hicks 2003, p. 167, italics original). Furthermore, Hicks assumes that a certain legal context exists in relation to the workplace.

\footnotetext{
${ }^{3}$ For a fuller engagement, see Kessler (2016) and Van den Heuvel (2017b).
} 
Gotsis and Kortezi, while being sympathetic to Hicks's proposal, note that his proposal for dealing with conflicts over spirituality in the workplace is based on a consequentialist foundation (Gotsis and Kortezi 2008). This is indeed the case: because while Hicks does, in part, include substantive accounts in defense of human dignity, for instance, his framework, as such, is not based on such substantive claims. Instead, it is an open-ended and mostly procedural attempt to reach consensus in conflicts over workplace spirituality. Hicks says: "I offer the framework of respectful pluralism in the hope that some or many readers will find it convincing and that those who disagree will offer a superior approach that addresses the circumstances of the contemporary workplace" (Hicks 2003, p. 166).

Gotsis and Kortezi deem such a consequentialist framework to be insufficient, and in reply they consider alternative foundations to workplace spirituality, making recourse to the other main schools of normative ethics, namely value ethics, deontological ethics, and virtue ethics. According to them, consideration of these other schools results in a richer approach to conflicts between differing spiritualities in the workplace. However, they don't concretize how the alternatives they offer would specifically achieve this enrichment, nor do they outline how potential differences arising from the application of these different approaches should be negotiated.

Furthermore, an important problem with Hicks's proposal, as well as with the response to it by Gotsis and Kortezi, is that the norms for deciding on spiritual practices do not derive from the spiritual journeys themselves, but come "from outside." 4 That is a major stumbling block for working with this approach in a spiritually diverse environment. Even though the approach hinges on the ability of the parties involved in the conflict to recognize their mutual equal dignity, and subsequently, the right of the other to respect, insufficient effort is made to make a case for this attitude that is based on the internal sources of the various spiritualities.

\subsection{Spirituality: A Social Construct?}

Connected to this is a third problem, namely the tendency by social scientists to primarily study spirituality within the framework of social constructivism (just one example is Hyde et al. 2014). Social constructivism as an approach is still in the process of forming, drawing on a number of disciplines, in particular psychology, history, and philosophy. Berger and Luckman's 1966 book The Social Construction of Reality, has been seminal. In it they claim that

There is only human nature in the sense of anthropological constants (. . .) that delimit and permit man's socio-cultural formations. But the specific shape into which this humanness is moulded is determined by those socio-cultural formations and relative to their numerous variations. While it is possible to say that man has a nature, it is more significant to say that

\footnotetext{
${ }^{4}$ In fact, Hicks himself recognizes the problem of such an approach when he critically discusses Rousseau's views on the civil religion. See Hicks (2003, p. 116).
} 
man constructs his own nature, or more simply, that man produces himself (Berger and Luckman 1991 [1966], p. 67).

This approach is a clear break with the view that human and social nature have a metaphysical basis, grounded, for example, in Christian theism. The methodological presuppositions of social constructivism have an immanent basis, which is exemplified in a further definition by Fiona Hibberd, according to whom "social constructivism emphasizes the historicity, the context-dependence, and the socio-linguistically constituted character of all matters involving human activity" (Hibberd 2005, p. viii; quoted in Sremac 2010, p. 10). This approach is suited to explicating many internal spiritual processes, again using psychology, for instance. But the often-unstated presupposition is that these constructions are all there is. As John Swinton and Harriet Mowat note: "The meaning and definition of reality is . . flexible, and open to negotiation depending on circumstances, perception, knowledge, power, structures and so forth" (Swinton and Mowat 2006, p. 36; quoted in Sremac 2010, p. 10).

This social constructive view on spirituality may resonate with those who accept that their own spirituality is indeed such a conditioned phenomenon. ${ }^{5}$ Most people, however, especially if they are theistic believers, will have difficulty accepting a social constructivist way of looking at their innermost beliefs and practices. Beyond such personal objections, there are also serious theological objections to be made against a purely social constructionist understanding of spirituality. Mark Wallace, for example, while generally positive about the potential of social constructivism for theology, nevertheless warns that this new school has a certain "tone deafness to the importance of alterity in the formation of self-hood" (Wallace 2002, pp. 108-109, italics original). He continues: "If subjectivity is reducible to culture, is there any place for the sometimes unique and distinctively 'other' voice of 'the good within' to tear apart the fabric of one's social relations in an effort to work out the meaning and truth of one's ownmost, radically individualistic, and oftentimes antisocial sense of the good?" (Wallace 2002, p. 109, italics original). ${ }^{6}$

It is important to be nuanced here. Steven Engler has pointed out that many studies on the relationship between social constructivism and the study of religion are too superficial, either because they misrepresent social constructivism as necessarily relativistic, or because they take the theory for granted to such an extent that it is no longer deemed necessary to explicate its workings (Engler 2005). When criticizing the dominance of social constructivism, it is especially important to be mindful of that first pitfall of unjustly equating social constructivism with relativism. In this connection, it is imperative to realize that as a working theory in the social sciences, social constructivism deliberately functions etsi Deus non daretur-it is a paradigm to be used in a specific context, without purporting to offer a total explanation of social and human life. As such, it is comparable with the paradigm of homo economicus, for example. Yet it still is the case that often the study of spirituality is in danger of the

\footnotetext{
${ }^{5}$ An example is the neuroscientist and well-known atheist Sam Harris-in his book, Waking Up, he is quite outspoken about his purely pragmatic choice for "stream of consciousness" (Harris 2014). ${ }^{6}$ For other criticisms, see for example Glaserfeld (2000).
} 
second pitfall, namely absolutizing the social constructivist paradigm, granting it more explanatory power than it warrants.

\subsection{Summary: The New "One-Dimensional Man”}

Together, a cynical use of calls for spirituality by some leaders who see it as a free (or at least relatively cheap) productivity boost, combined with a primarily utilistic way of dealing with spiritual differences, and underpinned by a radical application of the social constructivist framework, exacerbate the possibility that spirituality contributes to the creation of what Herbert Marcuse in his well-known 1964 book famously calls "the one-dimensional man" (Marcuse 1964). Marcuse claims that through the machinations of rationality and management, modern industrial societies seek to control human beings, especially their freedom, creativity, and initiative. Society, Marcuse says, is obsessed with control, seeking to make life manageable and one-dimensional. At the time, this book reverberated widely in Western societies. Marcuse's argument should now extend to the attention being paid currently to workplace spirituality - the reasons outlined above warrant that a critical "hermeneutics of suspicion" be applied. This is not to negate the importance of spirituality, but it is a recognition that the processes of commodification and control threaten genuine spirituality, as well as the richness and necessary multi-dimensionality of life, precisely by coopting the language of spirituality.

\section{The Different Spheres of Life: Contributions from a Protestant Concept}

In order to assist the related processes of discernment and leadership in this area, I want to help address the problems I have identified with the contemporary focus on spirituality in the workplace. In doing so, I focus on a Protestant theological concept, namely that of the different orders, or spheres of life, specifically as expounded by the German theologian Dietrich Bonhoeffer.

Martin Luther's conception of the Stände is an important source of the Protestant concept of the different orders of life. At its core, this doctrine claims that God rules the world through three different orders (Stände). As Luther describes in a key formulation in the 1528 Great Confession Concerning the Holy Supper: "But the holy orders and true religious institutions established by God are these three: the office of priest, the estate of marriage, the civil government" (Luther 1999, p. 364). Going back to older medieval concepts, Luther had already developed this doctrine 
before his break with Rome, ${ }^{7}$ and it forms an important cornerstone in his social ethics especially. In particular, it can be seen as a further specification of his important two-kingdom theory (on this, see Schirrmacher et al. 2001). The aim of this concept is to find a middle way between natural and theological ethics, or, in other words, between "the relative autonomy and immanence of Thomistic social ethics, in which nature is elevated and perfected by grace," and "the transcendental philosophical position according to which nature is not elevated but given greater profundity by grace ..." (Bayer 1998, pp. 146-147). Specifically, it allowed Luther to identify three different orders that structured social reality, discerning that each was governed by different laws which must be respected. In identifying these orders, Luther echoes distinctions found in Scripture-simultaneously, his concept echoes the world of the late Middle Ages, with "the estate of priest" encompassing the Church and the religious life, "the civil government" denoting the state, and "the estate of marriage" referring to the concept of oeconomia, which encompasses the often-intertwined spheres of "work" and "family life" (an example would be a farm, where the spheres of family life and work are deeply interwoven).

Much scholarship surrounds Luther's concept of the three orders of life. ${ }^{8}$ It is important to stress just how influential the Protestant concept of the different orders of life has become in the social history of the West. As Charles Taylor comments: "What is important for my purpose is this positive side, the affirmation that the fullness of Christian life was to be found within the activities of this life, in one's calling and in marriage and the family. The entire modern development of the affirmation of ordinary life was, I believe, foreshadowed and initiated, in all its facets, in the spirituality of the Reformers" (Taylor 1989, p. 218; quoted in Saarinen 2005, p. 195). ${ }^{9}$

In this chapter, I would like to focus particularly on how the Protestant concept of the orders of life is developed in the works of the German theologian Dietrich Bonhoeffer (1906-1945). While he has become best known for his role in the resistance against the Nazi regime, Bonhoeffer himself looked beyond the context of Nazism, considering the question of how Germany should be rebuilt after the war.

To help answer that question, he wrote his magnus opus, Ethics, which was intended to offer moral blueprints for the post-war society (Bonhoeffer 2005). In various of the Ethics manuscripts, Bonhoeffer makes recourse to the Lutheran concept of the different orders of life, seeking to revive that doctrine. ${ }^{10}$ In doing so, he suggests an alternative to the word Stände itself, arguing that it has lost its original meaning. In its place, he suggests the word Mandat (mandate). As well as

\footnotetext{
${ }^{7}$ Adam Francisco points out that by 1519 Luther has already discerned three basic orders of ordinary life. See Francisco (2007, p. 134).

${ }^{8}$ See, for example, Wingren (2004), Lohse (1995), Duby (1980), and Maurer (1970).

${ }^{9}$ On the significance of Luther's concept, see also Montover (2012, p. 113). An example of a thorough contemporary ethical appropriation of Luther's concept of the Stände is Ulrich (2005).

${ }^{10}$ Especially the manuscripts "Christ, Reality, and Good" (Bonhoeffer 2005, pp. 47-75) and "The Concrete Commandment and the Divine Mandates" (Bonhoeffer 2005, pp. 388-408). For more on Bonhoeffer's interaction with Luther, see DeJonge (2017, esp. pp. 130-131).
} 
the word changing, the concept itself also changes: instead of Luther's three orders, Bonhoeffer proposes four such orders: namely those of work, marriage, government, and church (Bonhoeffer 2005, p. 68). This means that the order of oeconomia is divided into two separate orders: the order of work, and the order of marriage. This change reflects the Industrial Revolution, in which for most people "work" was more distanced from family life-work for the office worker, the factory worker, or the miner was no longer as integral a part of their family lives. ${ }^{11}$

Like Luther, Bonhoeffer's intention with the concept of the divine mandates is to overcome the tension between living in the kingdom of God and simultaneously living "in the world," or, in Bonhoeffer's language, between the "worldly" and the "spiritual." He stresses that we have to live in both realities in the same time- the mandates are a heuristic tool to structure this living. As he says: "There can be no retreat . . . from a 'worldly' into a 'spiritual' 'realm.' The practice of the Christian life can be learned only under these four mandates of God" (Bonhoeffer 2005, p. 69).

Much critical debate surrounds Bonhoeffer's concept of the divine mandates, ${ }^{12}$ and it continues to be employed regularly in theological ethics. ${ }^{13}$ In what follows, I will draw out three particular characteristics of his concept, indicating how they can contribute to solving the problems with the contemporary emphasis on workplace spirituality that have been identified.

\subsection{The Mandates as a Restraint Against "Overstepping the Limit"}

Bonhoeffer's primary intent in developing the concept of the divine mandates is to protect the multicentered character of human and social life. In a key citation, Bonhoeffer asserts that "[o]nly in their being with-one-another [Miteinander], forone-another [Füreinander], and over-against-one-another [Gegeneinander] do the divine mandates of church, marriage and family, culture, and government communicate the commandment of God as it is revealed in Jesus Christ" (Bonhoeffer 2005, p. 393). The direct context of this assertion is the Nazi policy of Gleichschaltung, which attempted to bring all spheres of life into line with the powerful Nazi state. That meant, for example, that children in the Hitlerjugend were encouraged to give their loyalty to the Party first, rather than to their families. But the state also sought to intervene directly in the Church, as well as in other sectors of socio-economic life. Contrary to these developments, Bonhoeffer strongly asserted the relative

\footnotetext{
${ }^{11}$ This change is commented on by Ulrich Duchrow, who also notes that apart from that, Bonhoeffer's and Luther's concepts are identical. See Duchrow (1983).

${ }^{12}$ See, amongst others, the studies of the concept offered by Moltmann (1967), Mayer (1992), and De Lange (1996).

${ }^{13}$ See Scott (2007); and Van den Heuvel, "Bonhoeffer's Theology of Responsibility and the Social Dimension of Environmental Ethics," in Van den Heuvel (2017a, pp. 207-261).
} 
independence of each mandate, identifying this with God's creational intention of making the world a habitable place.

Although the context is very different, attempts at the instrumentalization of (organizational) spirituality, as well as narcissistic misdirection of this spirituality, can amount to a similar overstepping of the limits between the different spheres of life. In that context, the recognition of different spheres of life can be important in two regards. First, when "work" is concerned, the employee's orientation is not so much on the leader, but on the right ordering of their work - that is to say: to the structure, context, and directionality of that work, in the organization of which he or she is a part. Any organization seeks to attain certain goals, using certain means, within a specific context. Those boundaries are not just important for the essential self-identification of the organization, but also define the specific sphere and form of spirituality within that context. The leader is, in the end, not the only thing that counts, in that particular context, nor is the spiritual fulfilment of the employee-rather, within the specific context of the workplace, the goals, means, and context of the organization play a leading role (see Verkerk 2014).

Secondly, the recognition of the different spheres of life helps with the understanding of any organization - even one as venerable as a church, for example - as just one part of a rich, multidimensional reality; and it invites us not to find just one focal point for our spirituality - be it family, church, or the workplace; each is necessary for a rich, multifaceted spiritual existence. This may seem like stating the obvious, but there is a value in exploring further how the concept of orders can be a newer and better way of uncovering the dangerous and creeping tendencies of one-dimensionality. This leads me to the second contribution that the concept of the divine mandates can make.

\subsection{The Mandates as a Means to Appropriate Spiritual Pluralism: The Pragmatist Solution Revisited}

The grammar of the divine mandates also represents a way of negotiating conflicts between differing spiritualities. I have suggested above that pragmatist attempts, such as Hick's, that try to resolve such conflicts from the outside could be problematic. Bonhoeffer's doctrine of the divine mandates, on the other hand, represents an insider perspective - at least for many Protestant Christians. As I have stated, Bonhoeffer's key assertion about the divine mandates is that they are not to rule over each other. Specifically, this means that the state shouldn't try to dictate to the Church how it should organize itself; it also means that the Church is not to dictate how the economy should be run.

Bonhoeffer recognizes God's design in this system of orders that keep each other in check-he deliberately grounds his proposal in biblical texts (see, for example, Bonhoeffer 2005, p. 69). While one may argue about the solidness of this foundation, or about the definition Bonhoeffer gives to them, his concept-as a further development of Luther's concept—represents an attempt to negotiate the different spheres in 
life, as well as the tension between the "kingdom of God" and the "kingdom of the world." As a genuine "insider perspective." the doctrine of the divine mandates can help — at least from a Christian perspective - to appropriate differences in the spiritualities expressed in the workplace (on this, see also Kessler 2016).

The attitude to these will still be helpfully described by means of Hick's "respectful pluralism," but rather than being an outsider perspective, the Bonhoefferian concept of the divine mandates offers a more direct way for Christians to embrace this concept-it allows Christians to recognize that not all their deepest faith convictions are communicated in the same way in every sphere of life. The organization for which one works is not the same as one's church-and consequently, one's spirituality is expressed differently there. Not to recognize this can be criticized as trying to shortcut or overcome the world as it is, as happened in the Radical Reformation.

\subsection{The Mandates as a Middle Way Between Onto-Theology and Radical Social Constructivism}

Thirdly, Bonhoeffer's concept of the divine mandates can also assist in, on the one hand, appropriating a constructionist approach to spirituality, while on the other hand resisting its radical interpretation. Bonhoeffer asserts strongly that the different orders of life are not merely social constructs alone, but derive from God, from "above." He states:

By "mandate" we understand the concrete divine commission grounded in the revelation of Christ and the testimony of scripture; it is the authorization and legitimization to declare a particular divine commandment, the conferring of divine authority on an earthly institution. A mandate is to be understood simultaneously as the laying claim to, commandeering of, and formation of a certain earthly domain by the divine command (Bonhoeffer 2005, p. 389).

This assertion of the divine origin of the mandates may seem a blunt refusal of the validity of the whole project of investigating the social constructive dimension of religious beliefs and practices. However, Bonhoeffer doesn't revert to what Wallace calls an indefensible onto-theological conception of social reality "as it is" (Wallace 2002, p. 96). In contrast, Bonhoeffer grounds his concept of the divine orders simultaneously as structures brought about by God's will, as well as in the observation of reality itself. ${ }^{14}$ In the citation above, the primacy is on the commanding word of God-but at the same time there is a clear relationship between this

\footnotetext{
${ }^{14}$ Interestingly, Wallace, to whom I have just referred, recognizes in Bonhoeffer an example of someone whose life and theology pose a challenge to social constructivism. He argues that " $[\mathrm{t}] \mathrm{he}$ life and work of Dietrich Bonhoeffer is a ... counterexample to the constructionist emphasis on selfhood as a social predicate" (Wallace 2002, p. 109). Further on he explicates: "In fidelity to conscience, one may find oneself running the risk of violating social values and incurring personal guilt in pursuit of the responsible action in service to the neighbor" (Wallace 2002, p. 109).
} 
commandment and what Bonhoeffer calls the "earthly domain"-this means that while God's commandments come firmly "from above," there is a clear relationship with the "below," and the word of God does not function in isolation from that.

This is recognized by Moltmann, who emphasizes that the very nature of the mandates as commandments of the living God opens up the possibility for change within the mandates. As he puts it: "The negative rigidity which has been the object of complaint might be removed by integrating them into the living history of God. And then, finally, we shall see the law in the hand of the Lawgiver and the mandate in the hand of the God who commissions men to his service" (Moltmann 1967, p. 94). This is indeed correct, and it led Bonhoeffer to revise Luther's conception of the Stände, by breaking up the oeconomia into the different mandates of "work" and "family"-it also led him to muse about the possibility of a fifth mandate, in prison. ${ }^{15}$

Theologically speaking, Bonhoeffer thus occupies a middle position between the radical position of Karl Barth on the one hand, where all the emphasis is on the inbreaking word of God, ${ }^{16}$ and the reason-based Roman Catholic position on the other hand. ${ }^{17}$ Yet this middle-position of Bonhoeffer is not to be understood as an attempt to carefully delineate between the "religious" and the "secular," but precisely to overcome such attempts. Bonhoeffer's desire, fleshed out more fully in other manuscripts in his Ethics, is to speak about the world theologically and at the same time from a perspective etsi Deus non daretur, giving both their full due.

This dynamic of giving both perspectives their due can also be fruitful in relation to the question of how a social constructionist approach to spirituality can be appropriated. Adopting Bonhoeffer's "both-and" approach, one can say that spirituality isn't to be purely understood either as "God's work and nothing else," nor simply as a social construct. Rather, it recognizes the dynamic interplay of both elements at once, thus resisting both the negation, as well as the radical application of social constructivism. ${ }^{18}$

\footnotetext{
${ }^{15} \mathrm{He}$ does so in a letter to Renate and Eberhard Bethge, dated January 23, 1944 (Bonhoeffer 2010, pp. 264-271). In this letter, Bonhoeffer muses about adding a fifth mandate, namely that of "culture" (Kultur), a realm of freedom. As he puts it: "Someone who doesn't know anything of this sphere of freedom can be a good parent, citizen, and worker, and probably also be a Christian, but whether such a person is a full human being (and thus also a Christian in the fullest sense) is questionable to me" (Bonhoeffer 2010, p. 268).

${ }^{16}$ See Edward van't Slot, who comments: “. . . Barth prefers a more 'actualist' or 'eschatological' approach than Bonhoeffer in his ongoing quest for permanence in an ethics of God's commandment" (Van't Slot 2015, p. 206).

${ }^{17} \mathrm{Cf}$. Brian Brock, who says: "The mandates are thus not properly understood as metaphysical axioms, ethical blueprints, or programs; they are Christologically keyed signposts indicating the features of reality that allow us to encounter Christ" (Brock 2007, p. 90). See also Abromeit (1991, p. 135).

${ }^{18}$ Bonhoeffer's concept of the divine mandates is not the only way in which Christian thinking can overcome the false juxtaposition of onto-theology and constructionism. Within the tradition of Reformed Philosophy, for example, as developed by Dooyeweerd and others, an alternative has been developed. See Verkerk (2014).
} 


\section{Conclusion}

In this chapter I have presented the increasingly loud call for workplace spirituality as a double-edged sword. While recognizing its validity, as well as its promise for the contemporary workplace, I have drawn particular attention to the significant potential risks involved for the employees. Appeals for spiritual investment in the workplace can be used by manipulate and narcissistic leaders. Conflicts between different spiritualities are often superficially resolved, primarily making recourse to pragmatism for a solution. And, furthermore, radical social constructionist interpretations of spirituality do not do justice to the actual experience of (religious) spirituality.

In this context, I have made recourse to the Protestant concept of the different orders of life, as introduced by Luther and particularly as developed by Bonhoeffer. As a general concept, the idea of the different orders corresponds to the foundational human insight that, while we may strive for unity in our lives, in order to live full lives, we also need multidimensionality-we need to live in different "keys," corresponding to different spheres of life.

I have argued that the idea of the different mandates that Bonhoeffer puts forward is helpful with regards to the challenges identified. First, the recognition of the different spheres of life can illuminate attempts to manipulate workers into investing too much of their spirituality in the company-it may also help to deter manipulative and narcissistic leaders from demanding too much of their followers. Second, the mandates provide an answer on to how to deal with differences in spirituality, encountered in the workplace. Rather than accepting a pragmatic solution to these, the concept of the divine mandates provides an insider perspective to the appropriation of these differences, by recognizing the sphere of "work" to be different from that of the "church," thus urging a respect for pluralism that is founded in Christianity itself. Third, the concept of the mandates provides a way of accepting both the claim of deep authenticity of spirituality, as well as social constructivist appropriations of it.

In short, the concept of the different orders of life, as developed by Bonhoeffer, can function as a heuristic tool by means of which to correct some dangers to the current drive for more workplace spirituality. As such, this chapter contributes to the wider goal of this volume to contribute to the tasks of leadership and discernment with regards to the promising upsurge in spirituality.

Acknowledgements I would like to thank the participants in the conference "Leadership, Discernment and Spirituality," as well as two anonymous reviewers, for their comments on an earlier version of this chapter. Furthermore, I would like to thank Kay Caldwell for her help with the language editing of this chapter. 


\section{References}

Abromeit HJ (1991) Das Geheimnis Christi: Dietrich Bonhoeffers erfahrungsbezogene Christologie. Neukirchener Beitrage zur Systematischen Theologie 8. Neukirchener, Neukirchen-Vluyn

Atlaf A, Awan MA (2011) Moderating affect of workplace spirituality on the relationship of job overload and job satisfaction. J Bus Ethics 104:93-99

Bayer O (1998) Nature and institution: Luther's doctrine of the three orders. Lutheran Q 12 (2):125-159

Berger PL, Luckman T (1991) The social construction of reality: a treatise in the sociology of knowledge. Penguin, London

Block P (1993) Stewardship: choosing service over self-interest. Berrett-Koehler, San Francisco, CA

Bonhoeffer D (2005) Ethics, Dietrich Bonhoeffer works 6. Green CJ (ed). Fortress, Minneapolis, MN. Translated by Reinhard Krauss, Charles C. West and Douglas W. Stott

Bonhoeffer D (2010) Letters and papers from prison, Dietrich Bonhoeffer works 8. de Gruchy JW (ed). Fortress, Minneapolis, MN. Translated by Isabel Beste, Lisa E. Dahill, Reinhard Krauss, and Nancy Lukens

Brock B (2007) Singing the ethos of god: on the place of Christian ethics in scripture. Eerdmans, Grand Rapids, MI

DeJonge MP (2017) Bonhoeffer's reception of Luther. Oxford University Press, Oxford

Duby G (1980) The three orders: feudal society imagined. University of Chicago Press, Chicago, IL. Translated by Arthur Goldhammer

Duchrow U (1983) Dem Rad in die Speichen fallen—aber wo und wie? Luthers und Bonhoeffers Ethik der Institutionen im Kontext des heutigen Weltwirtschaftssystems. In: Gremmels C (ed) Bonhoeffer und Luther: Zur Sozialgestalt des Luthertums in der Moderne. Internationales Bonhoeffer Forum: Forschung und Praxis 6. Kaiser, Munich, pp 16-58

Engler S (2005) Two problems with constructionism in religion. Revista de Estudos da Religião 4:28-34

Francisco AS (2007) Martin Luther and Islam: a study in sixteenth-century polemics and apologetics. Brill, Leiden

Friedman TL (2016) Thank you for being late: an optimist's guide to thriving in the age of accelerations. Farrar, Straus and Giroux, New York

Glaserfeld E von (2000) Problems of constructivism. In: Steffe LP, Thompson PW (eds) Radical constructivism in action: building on the pioneering work of Ernst von Glasersfeld. Routledge/ Falmer, London, pp 1-9

Gotsis G, Kortezi Z (2008) Philosophical foundations of workplace spirituality: a critical approach. J Bus Ethics 78(4):575-600

Gupta M, Kumar V, Singh M (2014) Creating satisfied employees through workplace spirituality: a study of the private insurance sector in Punjab (India). J Bus Ethics 122(1):79-88

Harris S (2014) Waking up: a guide to spirituality without religion. Simon \& Schuster, New York

Heuvel SC van den (2017a) Bonhoeffer's Christocentric theology and fundamental debates in environmental ethics, Princeton theological monograph series 217. Wipf \& Stock, Eugene, OR

Heuvel SC van den (2017b) The dangers of charismatic leadership: a perspective from the theology of Dietrich Bonhoeffer. In: van den Heuvel SC, Barentsen J, Lin P (eds) The end of leadership? Christian perspectives on leadership and social ethics 4. Peeters, Leuven, pp 125-139

Hibberd FJ (2005) Unfolding social constructionism. Springer, Dordrecht

Hicks DA (2003) Religion and the workplace: pluralism, spirituality, leadership. Cambridge University Press, Cambridge

Holman D, Wall TD, Clegg CW, Sparrow P, Howard A (eds) (2005) The essentials of the new workplace: a guide to the human impact of modern working practices. Wiley, Chichester

Hyde B, Ota C, Yust K-M (2014) The deconstruction and social (re)construction of spirituality. Int J Child Spirituality 19(1):1-3

Isaacson W (2011) Steve Jobs. Simon and Schuster, New York 
Kessler V (2016) Bonhoeffer's doctrine of four mandates as a framework for decision-making within different contexts. In: Barentsen J, Kessler V, Meier E (eds) Christian leadership in a changing world: perspectives from Africa and Europe, Christian perspectives on leadership and Christian ethics 3. Peeters, Leuven, pp 61-76

Lambert L III (2009) Spirituality, Inc.: religion in the American workplace. New York University Press, London

Lange F de (1996) 'Miteinander, Fureinander, Gegeneinander': Bonhoeffers Mandatenlehre in einer pluralistischen Gesellschaft. Lecture, Siegen, September 27. http://home.kpn.nl/ delangef/artdbmandatduits.pdf. Accessed 14 Aug 2017

Lohse B (1995) Luthers Theologie in ihrer historischen Entwicklung und in ihrem systematischen Zusammenhang. Vandenhoeck \& Ruprecht, Göttingen

Luther M (1999) Word and sacrament III, Vol. 37 of Luther's works. Pelikan JJ, Oswald HC, Lehmann HT (eds). Fortress, Philadelphia, PA

Marcuse H (1964) One-dimensional man: studies in the ideology of advanced industrial society. Beacon, Boston, MA

Marques J, Dhiman S (eds) (2014) Leading spiritually: ten effective approaches to workplace spirituality. Palgrave Macmillan, New York

Maurer W (1970) Luthers Lehre von den drei Hierarchien und ihr mittelalterlicher Hintergrund. Bayerischen Akademie der Wissenschaften, Munich

Mayer R (1992) Die Bedeutung von Bonhoeffers Mandatenlehre für eine moderne politische Ethik. In: Mayer R, Zimmerling P (eds) Dietrich Bonhoeffer heute: Die Aktualitat seines Lebens und Werkes. Gießen, Brunnen, pp 58-80

Mitroff II, Denton EA (1999) A study of spirituality in the workplace. Sloan Manag Rev 40(4):83-92

Moltmann J (1967) The lordship of Christ and human society. In: Moltmann J, Weissbach J (eds) Two studies in the theology of Bonhoeffer. Scribner, New York

Montover N (2012) Luther's revolution: the political dimensions of Martin Luther's universal priesthood. James Clarke, Cambridge

Moran DJ (2010) ACT for leadership: using acceptance and commitment training to develop crisisresilient change managers. Int J Behav Consult Ther 6(4):341-355

Phipps K, Benefiel M (2013) Spirituality and religion: seeking a juxtaposition that supports research in the field of faith and spirituality at work. In: Neal J (ed) Handbook of faith and spirituality in the workplace: emerging research and practice. Springer, Dordrecht, pp 33-43

Saarinen R (2005) Ethics in Luther's theology: the three orders. In: Kraye J, Saarinen R (eds) Moral philosophy on the threshold of modernity, The new synthese historical library 57. Springer, Dordrecht, pp 195-219

Schirrmacher T, Vogt T, Peter A (2001) Die vier Schöpfungsordnungen: Kirche, Staat, Wirtschaft, Familie-bei Martin Luther und Dietrich Bonhoeffer. VTR, Nürnberg

Scott PM (2007) Postnatural humanity? Bonhoeffer, creaturely freedom, and the mystery of reconciliation in creation. In: Nielsen KB, Nissen U, Tietz C (eds) Mysteries in the theology of Dietrich Bonhoeffer: a Copenhagen Bonhoeffer symposium. Vandenhoeck \& Ruprecht, Gotingen, pp 111-134

Slot E van't (2015) Negativism of revelation? Bonhoeffer and barth on faith and actualism. Dogmatik in der Moderne 12. Mohr/Siebeck, Tubingen

Sremac S (2010) Converting into a new reality: social constructionism, practical theology and conversion. Nova Prisutnost 8(1):7-27

Swinton J, Mowat H (2006) Practical theology and qualitative research. SCM, London

Tarassenko V (2006) Kniga Bizness-Peremen: 64 Strategemy. Genesis, Moscow

Tarassenko V (2008) Ostorozno Stiven Kovi. Dobraia Kniga, Moscow

Taylor C (1989) Sources of the self. Cambridge University Press, Cambridge

Tourish D, Pinnington A (2002) Transformational leadership, corporate cultism and the spirituality paradigm: an unholy Trinity in the workplace? Hum Relat 55(2):147-172

Ulrich H (2005) Wie Geschöpfe Leben: Konturen Evangelischer Ethik. Lit, Berlin 
Verkerk M (2014) Spirituality, organization and leadership: towards a philosophical foundation of spirit at work. In: Nullens P, Barentsen J (eds) Leadership, innovation, and spirituality, Christian perspectives on leadership and social ethics, vol 1. Peeters, Leuven, pp 57-77

Wallace MI (2002) Losing the self, finding the self: postmodern theology and social construction. In: Hermans CAM, Immink G, de Jong A, van der Lans J (eds) Social constructionism and theology, Empirical studies in theology 7. Brill, Leiden, pp 93-111

Wingren G (2004) Luther on vocation. Wipf \& Stock, Eugene

Zinnbauer BJ, Pargament KI (2005) Religiousness and spirituality. In: Paloutzian RF, Park CL (eds) Handbook of the psychology of religion and spirituality. Guilford, London, pp 21-42

Steven C. van den Heuvel (Ph.D.) studied Pastoral Ministry at the Christelijke Hogeschool Ede, the Netherlands. He then went on to study theology at the Evangelische Theologische Faculteit (ETF), Leuven (Belgium), receiving his Th.M. in 2010, followed by his Ph.D. in 2015, as part of a joint doctorate with the Theologische Universiteit Kampen, the Netherlands. His dissertation was entitled Bonhoeffer's Christocentric Theology and Fundamental Issues in Environmental Ethics (Wipf and Stock, 2017). He is currently Postdoctoral Researcher in the department of Systematic Theology and Ethics at ETF and Senior Research Fellow of the Institute of Leadership and Social Ethics. Furthermore, he is Extraordinary Researcher at the Faculty of Theology at North-West University, South Africa.

Open Access This chapter is licensed under the terms of the Creative Commons Attribution 4.0 International License (http://creativecommons.org/licenses/by/4.0/), which permits use, sharing, adaptation, distribution and reproduction in any medium or format, as long as you give appropriate credit to the original author(s) and the source, provide a link to the Creative Commons licence and indicate if changes were made.

The images or other third party material in this chapter are included in the chapter's Creative Commons licence, unless indicated otherwise in a credit line to the material. If material is not included in the chapter's Creative Commons licence and your intended use is not permitted by statutory regulation or exceeds the permitted use, you will need to obtain permission directly from the copyright holder.

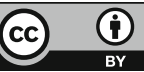

